\title{
PENDAMPINGAN PENERAPAN SOCIAL MEDIA MARKETING UNTUK PROMOSI PRODUK INDUSTRI KECIL DAN MENENGAH DI KABUPATEN BENGKALIS
}

\author{
Evawani Elysa Lubis, Rusmadi Awza, Rumyeni \\ Jurusan Ilmu Komunikasi, Fakultas Ilmu Sosial dan Ilmu Politik, Universitas Riau \\ e-mail: evawani.elysa.lubis@lecturer.unri.ac.id
}

\begin{abstract}
Abstrak
Bengkalis adalah salah satu kabupaten yang memiliki jumlah Industri Kecil dan Menengah (IKM/UKM) terbanyak di Provinsi Riau. Namun demikian beberapa tahun belakangan perolehan laba dari IKM/UKM di wilayah tersebut telah mengalami penurunan. Kondisi ini menjadikan IKM/UKM tersebut dituntut untuk lebih gencar melakukan kegiatan promosi agar produk-produk dari daerah tersebut lebih banyak dikenal dan dibeli oleh konsumen. Penggunaan media sosial sebagai media promosi sangatlah penting untuk diterapkan guna meningkatkan penjualan. Tujuan dari kegiatan ini adalah untuk memberikan pendampingan tentang penerapan pemasaran melalui media sosial (social media marketing) sebagai media promosi untuk produk-produk yang dihasilkan oleh pengusaha IKM dan juga Dinas Perindustrian dan Perdagangan (Disperindag) di Kabupaten Bengkalis. Kegiatan ini dilaksanakan selama empat bulan dengan kegiatan utama dilaksanakan di kantor Disperindag Kabupaten Bengkalis. Peserta yang hadir lebih dari empat puluh orang yang terdiri dari para pengusaha IKM yang ada di Bengkalis serta para staf dan pegawai Disperindag itu sendiri. Respon yang positif telah diberikan para peserta atas kegiatan tersebut. Dari kegiatan ini diketahui bahwa tidak seorang pun dari peserta yang menggunakan media sosial sebagai media promosi produk mereka. Sebagian besar peserta juga belum memiliki pengetahuan yang baik dalam menggunakan teknologi informasi berbasis internet. Melalui kegiatan pendampingan ini, para pengusaha IKM mendapatkan pengetahuan baru serta kemampuan awal dalam penerapan social media marketing yang sangat bermanfaat bagi pengembangan usaha terutama dalam hal promosi produk mereka.
\end{abstract}

Kata kunci: social media marketing, promosi, Industri Kecil dan Menengah (IKM)

\begin{abstract}
Bengkalis is one of the districts that has the largest number of Small and Medium Industries (IKM) in Riau Province. However, in the past few years, IKM's profitability in the region has decreased. This condition makes these IKMs demanded to do more and more incessant promotional activities so that products from these regions are more widely known and purchased by consumers. The use of social media as a promotional media is very important to implement in order to increase sales. The purpose of this activity is to provide training on the use of social media as a promotional media for IKM entrepreneurs and the Department of Industry and Trade in Bengkalis Regency. This activity was carried out for 4 (four) months by taking place at the Bengkalis Regency Industry and Trade Office. A total of approximately fifty people have been involved in this activity. The training participants consisted of staff and employees of the Bengkalis Regency Disperindag and IKM entrepreneurs domiciled in the Bengkalis Regency area.
\end{abstract}


This activity received a positive response from the training participants. From the activities carried out, it is known that not a single entrepreneur has used social media as a medium for promoting their products. In addition, most entrepreneurs also do not have good knowledge in using internet-based information technology. With this training activity, IKM entrepreneurs get new knowledge which is very useful for business development, especially in terms of promoting their products.

Keywords: social media marketing, promotion, small and medium industry

\section{Pendahuluan}

Keberadaan internet memunculkan paradigma baru mengenai pemasaran, berupa pemasaran modern berorientasikan pasar/konsumen atau revolusi pemasaran yang dikenal electronic marketplace (Amoot dan Bridgewater, 2002:86, Bakos, 1999:1613; Chaffey et.al,2000; Eid dan Trueman, 2002:54 dalam Sutejo 2006:2). Internet juga telah merubah cara perusahaan mendesain dan mengimplementasikan keseluruhan strategi bisnis dan pemasaran mereka. Internet juga mempengaruhi program komunikasi pemasaran dimana jutaan perusahaan baik yang multinasional sampai bisnis lokal telah mengembangkan website untuk mempromosikan produk dan jasa mereka dengan cara menyediakan informasi untuk menciptakan interaksi dengan calon konsumen. Fasilitas interaktif yang ditawarkan internet adalah salah satu keuntungan yang utama.

Perkembangan saat ini, istilah pemasaran menggunakan internet adalah internet marketing yang merupakan bagian dari integrated marketing communications (komunikasi pemasaran terpadu). Jika beberapa tahun lalu, produsen berkomunikasi secara massal melalui media konvensional seperti televisi, radio, media cetak, kini produsen berpikir ulang mengenai cara promosi produk yang tepat seiring perkembnagan zaman yang semakin maju. Internet marketing sering disebutjuga dengan pemasaran online melalui penggunaan teknologi internet (Jones, Malczyk, et.al, 2010:4)

Perkembangan internet marketing juga mendorong penggunaan media sosial dalam komunikasi pemasaran, atau dikenal juga dengan isti;ah social media marketing. Jenis media sosial yang terdapat dalam internet marketing yang digunakan sebagai alternatif untuk proses pemasaran dan melakukan interaksi dengan konsumen terdiri dari Youtube, Facebook, Twitter, Linkdln, Google+, Pinterest, Photo Sharing Sites, Podcast, Social Bookmarking, Geo Location, Q\&A Sites, dan Daiky Deal (Stelzner, 2013:29-36)

Dalam buku Brand of Think (2005) Rafi A Mohammed memberikan batasan internet marketing merupakan proses dalam mengembangkan dan menjaga customer relationship melalui aktivitas online yang merupakan pertukaran ide, produk, jasa yang berguna untuk memenuhi kepuasan konsumen (dalam Anggoro, et. al. 2009:14). Berdasarkan beberapa batasan tentang internet marketing tersebut maka dapat dtarik 
kesimpulan bahwa internet marketing adalah aktivitas pemasaran yang dilakukan dengna memanfaatkan media internet sebagai sarana komunikasi dan promosi produk maupun perusahaan itu sendiri. Terdapat tiga karakteristik khusus yang dimiliki oleh internet seperti yang diungkapkan Cleland (2000) bahwa internet membawa dampak besar jika digunakan pada pemasaran, yaitu: 1) Internet dengan dramatis dapat menghemat biaya informasi; 2) Internet dapat mewujudkan komunikasi dua arah yang interaktif; 3) Internet dapat mengurangi halangan dan keterbatasan ruang dan waktu. (dalam Andriyanto \& Haryanto. 2010:4)

Menurut Kotler dalam Widodo (2002), internet marketing mempunyai lima keuntungan besar bagi perusahaan yang memanfaatkannya. Pertama, semua perusahaan dapat memanfaatkannya baik perusahaan kecil maupun besar. Kedua, tidak terdapat batas nyata dalam ruang beriklan jika dibandingkan dengan media konvensional (cetak dan penyiaran). Ketiga, akses dan pencarian keterangan sangat cepat jika dibandingkan dengan surat kilat atau bahkan fax. Keempat, situsnya dapat dikunjungi oleh siapapun, dimanapun, dan kapanpun. Kelima, belanja dapat dilakukan secara lebih cepat dan sendirian. (dalam Andriyanto \& Haryanto. 2010:4).

Media sosial atau 'social media' dalam bahasa Inggris terdiri dari kata 'social' yang memiliki arti kemasyarakatan atau sebuah interaksi dan 'media' adalah sebuah wadah atau tempat sosial itu sendiri. Andreas Kaplan dan Micheal Haenlein, memberikan defenisi social media: a group of Internet-based applications that build on the ideological and technological foundations of Web 2.0, and that allow the creation and exchange of User Generated Content (Kaplan \& Haenlein, 2010:61). Social media marketing adalah sebagai sebuah proses yang memberdayakan individu dan perusahaan untuk mempromosikan website mereka, produk atau layanan online dan melalui saluran sosial untuk berkomunikasi dengan sebuah komunitas yang jauh lebih besar yang tidak mungkin tersebia melalui saluran periklanan tradisional (Drury, 2008:274). Penggunaan social media marketing selain untuk pemasaran juga untuk membunuh komentar negatif, dan untuk mendorong kesadaran secara keseluruhan dalam pasar dan terutama dalam pikiran dan hati para konsumen yang semakin tidak terjangkau oleh interruptive media (media tradisional). Singkatnya, banyak organisasi yang ikut mencari "keterlibatan" dan mereka melihat social media sebagai sarana pemasaran (Evans, Dave McKee, Jake, 2010:4).

Media sosial merupakan salah satu bagian dari strategi pemasaran, sehingga sebaiknya tidak berdiri sendiri. Berbagai komponen pemasaran dan media komunikasi lainnya, baik yang online atau offline, sebaiknya tetap dihubungkan dengan sosial media agar hasil yang diraih akan menjadi lebih maksimal. Jika memang Anda benar-benar serius memasarkan produk atau jasa di sosial media akan lebih baik jika membentuk divisi khusus yang menangani jalannya proses pemasaran di sosial media dan media online lainnya tersebut. 
Dalam memahami media sosial ada empat hal yang menurut Chris Heurer (dalam Solis, 2010:39), pendiri social media club dan inovator media baru yaitu 4C dalam pengoperasian media sosial, yaitu: a) Contex (konteks); bagaimana membingkai cerita yang disampaikan melalui pesan kepada audiens untuk mendapatkan atensi, , informasi serta promosi dan hal lainnya; b) Communications (komunikasi); adanya tindakan berbagi cerita, dimana pengguna dapat berperan sebagai yang mendengarkan, menjawab, yang merupakan bentuk respon. Komunikasi adalah proses penyampaian pesan berupa informasi yang nantinya akan membentuk pemahaman dan tanggapan serta umpan balik antara administrator dan pengguna.; c) Colaboration (Kolaborasi); adanya kerja sama antara pengguna media sosial sehingga tercipta hal yang efisien dan efektif, dan adanya kontribusi serta umpan balik melalui media sosial tersebut.; d) Connection (Koneksi); adanya hubungan yang terpelihara yang memberikan kenyamanan bagi pengguna media sosial tersebut.

Media sosial telah banyak dimanfaatkan oleh organisasi ataupun perusahaan dalam berbagai bentuk kegiatan, seperti pemasaran, komunikasi publik, kantor atau departemen yang berhubungan dengan konsumen dan stake holder ecara langsung, baik organisasi bisnis, nirlaba dan lebaga pemerintahan. Dalam aktivitas bisnis social media adalah salah satu saluran yang mendukung komunikasi dalam memasarkan barang dagangan secara cepat dan menguntungkan dibandingkan dengan menjual langsung ke pasar. Penggabungan social media dalam aktivitas pemasaran adalah untuk mendukung kinerja pemasaran seiring perkembangan teknologi dan informasi. Pemanfaatan social media marketing juga dapat dimanfaatkan oleh industri kecil dan menengah (IKM).

Transformasi struktur perekonomian Indonesia, dari yang berbasis agraria ke berbasis industri, khususnya industri manufaktur, telah mengalami stagnasi setelah krisis ekonomi yang melilit Indonesia pada medium 1997. Bahkan, kalau dilihat dari industri berskala besar, Indonesia telah mengalami deindustrialisasi. Meskipun demikian harapan bagi bangkitnya kembali sektor industri sebagaimana terjadi antara 1970-an sampai sebelum krisis ekonomi 1997, tidak ikut stagnan dimana untuk masuknya kelompok industri kecil dan menengah (IKM) ke pasar tidaklah resisten, walaupun pada saat krisis jumlah industri yang cukup besar mengalami penurunan namun jumlah industri kecil dan menengah mengalami kenaikan.

Sektor industri sebagai penggerak perekonomian telah mampu memberikan sumbangsih yang amat besar dan telah mempu menciptakan peluang kerja yang luas bagi masyarakat. Klasifikasi Industri menurut Peraturan Menteri Peindustrian RI No. 98/M-IND/12/2012 tentang Program Restrukturisasi Mesin/Peralatan IKM disebutkan bahwa industri dengan nilai investasi (di luar tanah dan bangunan tempat usaha) seluruhnya sampai Rp 500.000.000,- untuk industri kecil dan Rp 10.000.000.000,- untuk Industri Menengah. Industri kecil menengah (IKM) merupakan salah satu segmen industri yang dapat dijadikan tumpuan dalam penciptaan iklim wirausaha yang dapat menyerap tenaga kerja. IKM sudah terbukti ketangguhannya dapat bertahan terhadap 
badai krisis ekonomi periode reformasi tahun 1997-1998 karena memiliki fleksibilitas dan elastisitas yang tinggi. Karakteristik inilah yang memberikan andil cukup signifikan untuk mewujudkan perekonomian daerah yang tangguh yang bercirikan kerakyatan. (www.disperindagkop.tanahbumbukab.go.id)

Pengembangan IKM perlu mendapatkan perhatian yang besar baik dari pemerintah maupun masyarakat agar dapat berkembang lebih kompetitif bersama pelaku ekonomi lainnya. Pemerintah pada intinya memiliki kewajiban untuk turut memecahkan tiga hal masalah klasik yang kerap kali menerpa IKM, yakni akses pasar, modal dan teknologi. Secara keseluruhan terdapat beberapa hal yang harus diperhatikan dalam melakukan pengembangan terhadap unit usaha IKM, antara lain kondisi kerja, promosi usaha baru, akses informasi, akses pembiayaan, akses pasar, peningkatan kualitas produk dan Sumber Daya Manusia (SDM), ketersediaan layanan pengembangan usaha, pengembangan cluster, jaringan bisnis, dan kompetisi.

Keberadaan IKM di suatu daerah sangatlah penting artinya untuk menopang perekonomian daerahnya. Kabupaten Bengkalis adalah salah satu kabupaten di Provinsi Riau yang memiliki jumlah IKM terbanyak sebesar \pm 4800 unit. Berdasarkan informasi dari Dinas Perindustrian dan Perdagangan Kabupaten Bengkalis menyebutkan Perkembangan IKM di Kabupaten Bengkalis terus meningkat setiap tahunnya. Secara umum pertumbuhan industri kecil dan menengah (IKM) di Kabupaten Bengkalis tahun 2016 mengalami pertumbuhan yang signifikan dibandingkan dengan data tahun 2015 . Hal ini dapat dilihat pada tabel berikut ini.

Tabel 1

Data Kondisi IKM di Kabupaten Bengkalis 2015 \& 2016

\begin{tabular}{lll}
\hline Kondisi & 2015 & 2016 \\
\hline Jumlah IKM & 3.321 & 4.805 \\
\hline Profit/Laba (Rupiah) & $40.997 .212 .000,-$ & $37.138 .734 .000,-$ \\
\hline Tenaga Kerja & 6.190 & 8.508 \\
\hline
\end{tabular}

Sumber: Dinas Perindustrian dan Perdagangan Kab. Bengkalis Riau, 2017

Sementara itu sektor industri yang cukup berkembang di Kabupaten Bengkalis adalah sektor industri barang dan logam, makanan dan minuman, batu bata, kain tenun dan pintal, furniture, dan lain sebagainya. IKM ini tentu telah memberikan pemasukan (income) bagi daerah Bengkalis tersebut.

Kabupaten Bengkalis yang pada tahun 2016 adalah salah satu daerah yang memiliki jumlah industri kecil dan menengah terbanyak di Provinsi Riau dengan jumlah 4.805. Dari jumlah IKM tersebut telah memberikan profit atau laba sebesar \pm 37 milyar rupiah sementara itu pada tahun 2015 jumlah IKM lebih sedikit (3.321) namun 
meperoleh profit hampir mendekati 41 milyar. Dari kondisi ini terlihat bahwa telah terjadi penurunan perolehan laba dari IKM yang ada di Bengkalis dan dari informasi yang didapatkan diketahui bahwa kegiatan promosi yang dilakukan oleh IKM maupun oleh Dinas Perindustrian dan Perdagangan Kabupaten Bengkalis belum maksimal.

Promosi adalah salah satu strategi pemasaran untuk memenangkan pasar. Suatu produk yg bermutu dan bermanfaat jika tidak dikenal oleh konsumen, maka produk tsb tidak akan dibeli. Promosi merupakan proses mengkomunikasikan variabel bauran pemasaran (marketing mix) yg sangat penting dilaksanakan oleh perusahaan dalam memasarkan produk. Inti dari kegiatan promosi adalah suatu bentuk kegiatan komunikasi pemasaran yang berusaha untuk menyebarkan informasi, mempengaruhi, mengingatkan pasar sasaran agar bersedia menerima, membeli dan loyal pada produk yg ditawarkan perusahaan. Tujuan kegiatan Promosi (Kotler, 2004) yakni: 1) Menciptakan atau meningkatkan awarness produk atau brand; 2) Meningkatkan preferensi brand pada target pasar; 3) Meningkatkan penjualan dan market share; 4) Mendorong pembelian ulang merek yg sama; 5) Memperkenalkan produk baru; 6) Menarik pelanggan baru.

Kegiatan promosi yang telah dilakukan adalah mengadakan pameran, pekan industri makanan tahunan, memberikan penghargaan kepada pelaku IKM yang berbakat serta memberikan edukasi seputar langkah awal membangun industri kecil dan menengah. Dari kegiatan promosi yang telah dilakukan terlihat penggunaan media promosi kuranglah maksimal. Media promosi seperti iklan di media massa maupun media sosial mempunyai peranan penting dalam meningkatkan penjualan produk. Penggunaan media sosial sebagai media promosi sangatlah penting untuk dilaksanakan guna meningkatkan penjualan. Oleh karena itu perlulah dilakukan pendidikan dan penyuluhan tentang pemanfaatan media sosial dalam promosi tersebut oleh para pengusaha IKM maupun Dinas Perindustrian dan Perdagangan Kabupaten Bengkalis.

Tujuan dari kegiatan pelatihan pemanfaatan media sosial sebagai media promosi bagi UKM/IKM di Kabupaten Bengkalis ini adalah memberikan pemahaman kepada pengusaha UKM/IKM tentang manfaat penggunaan media sosial sebagai media promosi bagi usaha ataupun produk yang dihasilkannya. Kemudian kegiatan pengabdian ini juga bertujuan memberikan pelatihan dan pendampingan kepada para pengusaha UKM/IKM dalam pemanfaatan media sosial untuk kegiatan promosi produk yang dihasilkan sehingga diharapkan dapat meningkatkan penghasilan mereka.

Manfaat yang diharapkan dari kegiatan pengabdian kepada masyarakat berupa pelatihan pemanfaatan media sosial sebagai media promosi bagi UKM/IKM ini adalah bagi para pengusaha UKM/IKM, pelatihan ini dapat meningkatkan pengetahuan, pemahaman dan kemampuannya dalam pemanfaatan media sosial sebagai media promosi ataupun transaksi usaha yang dimilikinya. Kemudian kegiatan ini juga bermanfaat bagi para pegawai Disperindag Kabupaten Bengkalis karena dapat meningkatkan pengetahuan dan pemahaman tentang media sosial sebagai media 
promosi sehingga dapat memberikan masukan untuk program pembinaan UKM/IKM selanjutnya. Sementara itu bagi dosen, kegiatan ini bermanfaat untuk pengembangan ilmu yang dimiliki serta merupakan bentuk pengabdian diri kepada masyarakat sesuai dengan tuntutan Tri Dharma Perguruan Tinggi.

\section{Metode}

Metode yang digunakan dalam kegiatan pengabdian kepada masyarakat ini adalah dengan cara memberikan pelatihan kepada peserta yang terdiri dari pengusaha UKM dan pegawai Disperindag Kabupaten Bengkalis. Media yang digunakan adalah infocus sebagai alat dalam penyampaian materi, laptop dengan koneksi internet sebagai media pembuatan akun media sosial dan fanpage, serta brosur yang digunakan sebagai panduan kepada peserta untuk mempermudah langkah-langkah dalam pembuatan media promosi melalui media sosial.

Rangkaian kegiatan pengabdian kepada masyarakat ini dilakukan selama 4 (empat) bulan yang terdiri dari beberapa tahapan yaitu: a) Mempersiapkan bahan atau materi yang diperlukan pada Pelatihan Pemanfaatan Social Media Marketing Sebagai Media Promosi Produk Industri Kecil Dan Menengah (IKM) Di Kabupaten Bengkalis, Kabupaten Bengkalis; b) Mengadakan pertemuan sesama tim penyuluhan untuk mendiskusikan materi kegiatan yang akan dilaksanakan dan pembagian tugas antar tim pelaksana. c) Mengadakan pertemuan dengan Kepala Dinas Perindustrian dan Perdagangan Kabupaten Bengkalis guna mendapatkan izin pelaksanaan dan penetapan jadwal kegiatan.; d) Mengadakan pelatihan pemanfaatan social media marketing sebagai media promosi produk industri kecil dan menengah (IKM) di Kabupaten Bengkalis, Kabupaten Bengkalis.

\section{Hasil dan Pembahasan}

Kegiatan pendampingan penerapan social media marketing untuk promosi produk bagi para pengusaha IKM di Kabupaten Bengkalis ini dapat berjalan sebagaimana yang diharapkan oleh tim pengabidan kepada masyarakat ini. dari kegiatan tersebut di awal diketahui bahwa para peserta sebagian besar belum mengetahui tentang manfaat media sosial sebagai media komunikasi pemasaran atau untuk media promosi produk mereka. Dan yang paling mendasar dari kegiatan ini juga diketahui bahwa ada sebagian dari peserta pendampingan ini yang belum mengetahui tantang pentingnya promosi produk yang dihasilkannya. Mereka hanya memproduksi produk dan menjualnya kepada agen atau distributor yang lebih besar dengan harga yang tidak terlalu tinggi, Namun demikian para peserta sangat menyambut baik akan kegiatan pendampingan tersebut.

Tim pengabdian kepada masyarakat ini juga melakukan pendekatan dan 
komunikasi secara informal dengan para peserta. Dari komunikasi tersebut diketahui bahwa sebagian para peserta masih sangat minim pengetahuannya tentang pemanfaatan teknologi internet maupun media sosial, sehingga tim berinisiatif memberikan pemahaman terlebih dahulu tentang teknologi internet dan media sosial tersebut. Namun demikian dari hasil observasi tim pengabdian kepada masyarakat ini diketahui bahwa sebagian besar peserta telah memiliki perangkat telepon pintar yang dapat terhubung dengan internet dan dimanfaatkan untuk mengembangkan pemasaran produk mereka melalui media sosial.

Pada kegiatan pendampingan ini diawali dengan penyuluhan kepada peserta yang merupakan pengusaha industri kecil dan menengah (IKM/UKM) serta pegawai Disperindag Bengkalis tentang perkembangan media sosial yang tidak hanya dapat digunakan untuk menghubungi saudara ataupun sahabat namun media sosial juga dapat dimanfaatkan untuk pemasaran produk dari hasil suatu usaha. Pada pelaksanaan awal tim mencoba mengobservasi tentang keterlibatan peserta dalam penggunaan media sosial. Dari hasil observasi tersebut diketahui bahwa sebagian peserta mengetahui tentang media sosial dan memiliki perangkat teknologi komunikasi berupa telepon pintar untuk mengakses media sosial tersebut. Diketahui pula bahwa media sosial yang paling banyak diakses oleh peserta adalah Facebook dengan tujuan untuk mencari teman baru, bersilaturahmi dengan keluarga dan sahabat serta mem-posting hal hal yang dianggap menarik diketahui oleh sahabat dan keluarganya. Namun dalam hal pemanfaatan media sosial sebagai media promosi dalam komunikasi pemasaran bagi usaha para IKM/UKM belum menjadi media alternatif dalam kegiatan promosinya.

Kegiatan penyuluhan dan pendampingan penerapan social media marketing ini diikuti oleh pesertanya dengan sangat antusias. Mereka sangat ingin mengetahui cara pembuatan dan pengelolaan media sosial yang mereka miliki menjadi media promosi bagi usaha mereka. Hal ini disebabkan karena pemanfaatan media sosial untuk media promosi sangatlah mudah dan tidak memerlukan biaya yang besar.

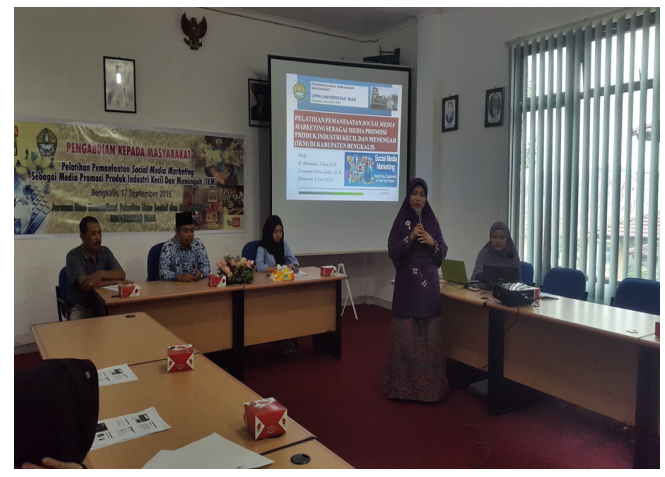

Gambar 1: Pemaparan materi oleh Tim Pengabdian, Bengkalis (2018)

Sebelumnya para pengusaha industri kecil dan menengah tersebut tidak tertarik untuk merancang program komunikasi pemasaran ataupun promosi dalam memasarkan produk yang diproduksinya. Kegiatan promosi yang dilakukannya hanya 


\section{MENARA RIAU}

Jurnal Ilmu Pengetahuan

dan Pengembangan Masyarakat Islam

Vol. 15, No. 01, April, 2021, pp. $22-32$
Evawani Elysa Lubis, Rusmadi Awza, Rumyeni

Pendampingan Penerapan Social Media

Marketing untuk Promosi Produk Industri

Kecil dan Menengah di Kabupaten Bengkalis

sebatas pembukaan toko atau outlet dan mengandalkan informasi dari mulut ke mulut (WOM/Word of Mouth). Namun mereka sadari bahwa langkah yang mereka lakukan untk pengembangan usahanya kurang dapat menjangkau target konsumen yang luas. Sementara itu jika memanfaatkan media konvensional untuk promosi produknya akan membutuhkan dana yang cukup besar. Oleh sebab itu media promosi melalui media sosial ini dapat menjadi media alternatif yang memberikan keuntungan kepada para pengusaha IKM/UKM di Bengkalis.

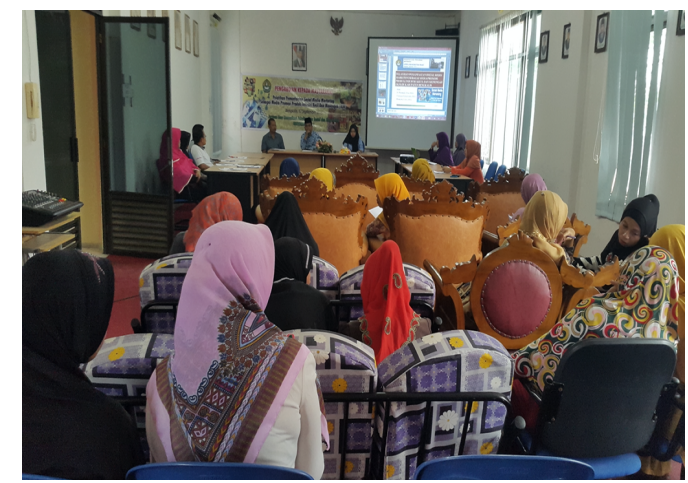

Gambar 2: Sesi Diskusi, Bengkalis (2018)

Pada kegiatan ini tim pengabdian memberikan pelatihan dan pendampingan kepada peserta untuk membuat akun media sosial seperti facebook, karena sebagain besar peserta telah mengetahui media sosial tersebut. Kemudian tim juga mendampingi pembuat fanpage untuk usaha yang dimiliki oleh para pengusaha IKM/UKM. Selain itu tim juga melatih peserta dalam pembuatan foto produk yang menarik dan menguploadnya ke akun facebook dan fanpage mereka. Diakhir kegiatan ini dilengkapi dengan penjelasan dari tim tentang strategi pemasaran di media sosial seperti facebook.

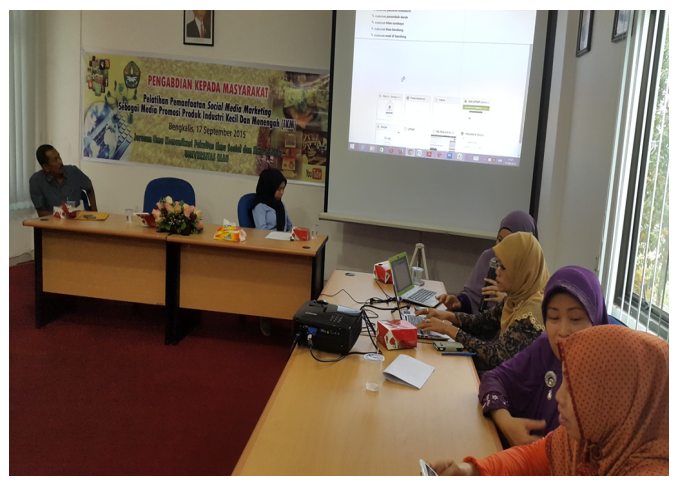

Gambar 3. Proses Pendampingan Penerapan Social Media Marketing kepada Pelaku Usaha IKM di Bengkalis (2018)

Dari pelaksanaan kegiatan pendampingan tersebut tim dapat memahami bahwa pendampingan dan penyuluhan ini merupakan langkah awal sebagai pengenalan tentang penerapan social media marketing untuk promosi produk yang dihasilkan oleh IKM/UKM. Untuk selanjutnya tim juga memberikan kesempatan kepada peserta pendampingan dan penyuluhan ini yang ingin berkonsultasi lebih lanjut tentang pengelolaan media sosialnya sebagai media promosi produk mereka. Oleh karena itu Tim Pengabdian telah memberikan nomor kontak yang dapat dihubungi oleh peserta. Pada pelatihan ini sebagian peserta dapat mengikuti petunjuk yang diberikan oleh tim 
untuk membuat fanpage tersebut. Namun ada juga peserta yang belum dapat mengikutinya karena keterbatasan pemahaman dan gadget yang dimiliki.

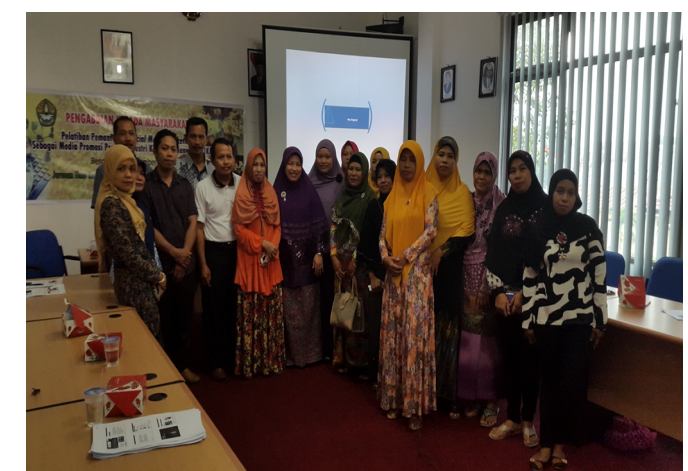

Gambar 4: Foto bersama narasumber dan peserta, Bengkalis (2018)

Pelaksanaan kegiatan pendampingan ini ternyata memiliki beberapa hal yang menjadi faktor penghambat dan juga faktor pendukung keberhasilan kegiatan tersebut. Dari segi faktor penghambat, terdapat beberapa kendala dalam pelaksanaannya. Kendala pertama yang dihadapi oleh tim pengabdian kepada masyarakat ini adalah keterbatasan waktu dan dana mengakibatkan tim pelaksana tidak dapat melaksanakan kegiatan ini secara lebih intensif sehingga masih ada pemintaan baik dari pihak Dinas Perindustrian dan Perdagangan Kabupaten Bengkalis maupun pengusaha IKM/UKM. Selanjutnya hambatan yang dihadapi adalah masih adanya pengusaha IKM/UKM yang belum memahami dengan baik penggunaan teknologi baik smartphone maupun komputer sebagai sarana dalam menjalankan aplikasi media sosial.

Walaupun dalam pelaksanaan kegiatan ini ada beberapa faktor yang menjadi penghambatnya, namun ada juga beberapa hal yang menjadi faktor penfukung kegiatan ini. Pertama, pelatihan yang diberikan ini merupakan salah satu upaya untuk membantu pemahaman dan meningkatkan kesadaran pengusaha kecil menengah tentang pentingnya penggunaan teknologi untuk menunjang kegiatan promosi produk sehingga produk tersebut lebih dikenal dan untuk meningkatkan volume penjualan. Kedua, antusiasme yang tinggi dari peserta pelatihan baik dari Disperindag Kabupaten Bengkalis maupun para pelaku IKM menjadikan pelatihan ini berjalan dengan baik dan memberikan manfaat bagi para peserta. Ketiga, materi yang diberikan sangat menarik untuk diikuti sehingga peserta yang hadir dalam kegiatan tersebut cukup banyak dan diantaranya yang hadir mempunyai sikap dan rasa ingin tahu yang tinggi.

\section{Simpulan}

Hasil evaluasi menunjukkan dari kegiatan tanya jawab yang dilakukan terhadap para peserta pelatihan, ternyata materi yang disampaikan memberikan manfaat yang sangat besar dan dibutuhkan oleh peserta pelatihan tersebut, bahkan mereka 
Evawani Elysa Lubis, Rusmadi Awza, Rumyeni

Pendampingan Penerapan Social Media Marketing untuk Promosi Produk Industri Kecil dan Menengah di Kabupaten Bengkalis

mengharapkan kegiatan ini berkelanjutan dengan memberikan materi secara lebih dalam dan memberikan tutorial pembuatan media promosi yang berbeda.

Mengingat besarnya manfaat kegiatan pengabdian pada masyarakat ini, maka selanjutnya perlu mengadakan pelatihan serupa dengan sasaran khalayak yang lebih luas. Selanjutnya juga harus ada kesinambungan dan monitoring program pasca kegiatan pengabdian ini sehingga pelaku IKM bisa benar-benar menerapkan pengetahuan yang telah mereka peroleh pada kegiatan pelatihan ini.

\section{Referensi}

Anggoro, et. al. 2009. Direct Marketing dan Online Marketing. Jakarta: Universitas Sahid.

Ardianto, Elvinaro. 2010. Metode Penelitian untuk Public Realtions Kuantitatif dan Kualitatif. Bandung: Simbiosa Rekatama Media.

Evan, Dave. Mckee, Jake. 2010. Social media marketing: The Next Generations of Business Engagement. Canada: Wiley Publishing.

Kaplan, A.M. \& Haenlein. M. 2010. Users of The World. Unite! The Challenges and Oppurtunities of Social Media. Bussines Horizons. 53. 59-68.

Kotler, Philip. 2004. Manajemen Pemasaran. Jilid 1 dan Hilid 2 Edisi Milienium. Jakarta: Prenhallindo.

Shimp, Terence A. 2003. Periklanan Promosi Aspek Tambahan Komunikasi Terpadu. Jakarta: Erlangga

Solis, Brian. 2011. Engage: The Complete Guide for Brands and Businesses to Build. Cultivate. and Measure Succes in the New Web. New Jersey: John Wiley \& Sons

Stelzner, A. Micheal. 2013. 2013 Social media marketing Industry Report: How Marketeers Are Using Social Media to Grow Their Bussinesses. Social Media Examiner.

www.disperindagkop.tanahbumbukab.go.id/industri_kecil_menengah/2012 